\title{
リンゴポリフェノールによる易肥満性ラットの脂質代謝 およびインスリン非依存性の改善
}

\author{
太田 豊 ${ }^{\S}$, 船山 誠*, 清野博威*, 佐見 学, 神田智正, \\ 庄司俊彦，大竹康之，長田恭一* \\ アサヒビール株式会社未来技術研究所 \\ * 弘前大学農学生命科学部
}

\author{
Apple Polyphenol Improves Lipid Metabolism and Insulin Independence in Obese Rats \\ Yutaka Ohta ${ }^{\S}$, Makoto Funayama*, Hirotake Seino*, Manabu Sami, Tomomasa Kanda, \\ Toshihiko Shoji, Yasuyuki Ohtake and Kyoichi Osada* \\ Fundamental Research Laboratory, Asahi Breweries, Ltd., \\ I -21, Midori 1-chome, Moriya-shi, Ibaraki 302-0106 \\ *Faculty of Agriculture and Life Science, Hirosaki University, \\ 3 Bunkyo-cho, Hirosaki, Aomori 036-8561
}

\begin{abstract}
We evaluated the effects of apple polyphenol (AP), of which the major components are procyanidins, on obesity and glucose tolerance using Zucker fatty rats (fa/fa). In this study, Zucker fatty rats were fed diets containing $0.2 \%$ or $1.0 \%$ apple polyphenol for 12 weeks. Visceral fat weight and triglyceride levels in blood and liver were reduced by AP intake. Glucose and insulin levels in blood also decreased, and the amount of fatty acids excreted into feces increased in dose-dependent manner. Furthermore, suppression of fatty acid synthase gene expression in the liver and increase of adiponectin gene expression in white adipose tissues were observed. These results indicate that AP improves lipid metabolism and insulin resistance.
\end{abstract}

(Received Feb. 26, 2007 ; Accepted Mar. 19, 2007)

Keywords : apple, procyanidins, obesity, Zucker fatty rat, insulin resistance

キーワード：リンゴ，プロシアニジン，肥満，Zucker fattyラット，インスリン抵抗性

肥満は多くの国で年々増加している社会問題1)であり, 主として食事や運動などの日常の生活習慣に起因する。肥 満之高脂血症, 高血糖や高血圧との併発により， II 型糖尿 病, 冠動脈疾患や脳血管疾患のリスクが飛躍的に高まるこ とが，いわゆる「メタボリックシンドローム」と呼ばれる 概念として広く知られるようになった ${ }^{2) ~ 5)}$.

食品成分の中には，脂質代謝改善効果や，血糖值低減効 果を持つものが見出されている。緑茶由来力テキン類の摂 取による, 実験動物およびヒトの血清脂質濃度低減効果や 内臓脂肪蓄積抑制効果が報告されている ${ }^{6) \sim 11)}$. さらに, 緑 茶由来カテキン類摂取がラットの血中インスリン濃度や血 糖值を低下させ，耐糖能異常を改善することが示唆され た ${ }^{12) 13)}$.

リンゴ (Malus pumila) はプロシアニジン類を主成分と

干302-0106 茨城県守谷市緑 1-1-21

* =036-8561 青森県弘前市文京町 3

$\S$ 連絡先 (Corresponding author), yutaka.ohta@asahibeer.co.jp
するポリフェノールを含有する ${ }^{14)}$ ，プロシアニジン類はカ テキンおよびエピカテキンが縮合重合したオリゴマーであ り，リンゴには $2 \sim 15$ 量体のプロシアニジン類が存在する ことが確認されている(15) 17). 一方，プロアントシアニジン 類を含有するポリフェノールであるブドウ種子抽出物 ${ }^{18)}$, 松樹皮抽出物 ${ }^{19)}$ の摂取が血清脂質濃度を改善することが 報告されている。これらより，プロアントシアニジン類の 摂取が肥満，高脂血症や高血糖などの症状を緩和すると期 待されている.

「一日一個のリンゴは医者を遠ざける」と言われるよう に，古来よりリンゴの摂取は健康に寄与すると考えられて いる．筆者らは既に，プロシアニジン類を主成分とするリ ンゴポリフェノール（以下「AP」と称す）の摂取が，高脂 肪食飼育ラットの内臓脂肪蓄積を抑制すると報告した ${ }^{20)}$. また, AP の安全性 ${ }^{21}$ おょひびヒト経口摂取 (600 mg/day を 12 週間) による内臓脂肪量低減効果 ${ }^{22}$ を報告した。本研究 では，通常食飼育においても過食による肥満や高インスリ 
Table 1 The composition of diets

\begin{tabular}{lccc}
\hline \multirow{2}{*}{ Component } & \multicolumn{3}{c}{ group } \\
\cline { 2 - 4 } & Control & AP 0.2\% & AP 1\% \\
\hline components & \multicolumn{3}{c}{ weight \% } \\
Cornstarch & 18.8 & 18.6 & 17.8 \\
Casein & 20.0 & 20.0 & 20.0 \\
$\alpha$-Cornstarch & 13.2 & 13.2 & 13.2 \\
Sucrose & 13.0 & 13.0 & 13.0 \\
Corn oil & 25.0 & 25.0 & 25.0 \\
Cellulose & 5.0 & 5.0 & 5.0 \\
Mineral mix (AIN93) & 3.5 & 3.5 & 3.5 \\
Vitamin mix (AIN93) & 1.0 & 1.0 & 1.0 \\
L-Cystine & 0.3 & 0.3 & 0.3 \\
Choline bitartrate & 0.2 & 0.2 & 0.2 \\
AP & 0.0 & 0.2 & 1.0 \\
\hline
\end{tabular}

ン血症を呈し, 非インスリン依存性糖尿病を発症するレプ チン受容体遺伝子欠損動物 Zucker fatty ラット（fa/fa）を 用い, 内臓脂肪蓄積, 血中脂質濃度および血糖值やインス リン濃度に対する AP 摂取の効果を検討した。

\section{実 験 方 法}

\section{1. 実験動物と飼料調製}

5 週齢の Zucker fatty ラット (Crj : (ZUC)-fa/fa ; 日本 チャールズリバー）を室温 $\left(20-23^{\circ} \mathrm{C}\right.$ ), 明暗時間制御（明 期 8：00-20:00）のもと, 個別ケージにて飼育した. 1 週間 の馴化飼育の後，平均体重がそれぞれ均等となるように 6 匹ずつ 3 群に分けた. AP を含む飼料は AIN-93G を元に作 製し. 成分組成を Table 1 に示す. AP に含まれるポリ フェノール成分をTable 2 に示す. APを $0.2 \%$ まは $1.0 \%$ 含有する飼料を摂取した群を，それぞれ「AP 0.2\% 群」または「AP $1 \%$ 群」と称する. ペアフィーディングに よる飼育を 88 日間行った後, 一夜絶食の後, ジェチルエー テル麻酔下で腹部大動脈より採血を行い, 血清と EDTA 血漿を取得した. 本動物実験は弘前大学実験動物倫理委員 会の指針に従い行った。

\section{2. 脂質の分析, 肝臓の分画および酵素活性測定}

肝臓および血清中の脂質は Folch らの方法により抽出 し ${ }^{23)}$, 既報にて述べた方法で測定を行った ${ }^{24)}$.また, 肝臓の 酵素活性を測定するため, 氷冷下， $1 \mathrm{mM}$ EDTA および 3 $\mathrm{mM}$ Tris- $\mathrm{HCl}$ を含む 7 倍容の $0.25 \mathrm{M}$ ショ糖破砕溶液 $(\mathrm{pH}$ 7.2) に肝臓組織小片 (約 $3 \mathrm{~g}$ ) を入れホモジナイゼーション を行い, 肝組織懸濁液を得た。この懸濁液を $4^{\circ} \mathrm{C}, 500 \times \mathrm{g}$ で 10 分間遠心分離した. 得られた上清をさらに $4^{\circ} \mathrm{C}, 9000$ $\times \mathrm{g}$ で 10 分間遠心分離し, 上清と沈殿を分取した.この上 清をさらに $4^{\circ} \mathrm{C}, 105000 \times \mathrm{g}$ で 60 分間遠心分離を行い, 沈殿をペルオキシソーム画分, 上清をサイトゾル画分とし た。サイトゾル画分の Fatty acid synthase 活性測定は Nepokroeff らの方法に従い ${ }^{25)}, 0.4$ mM EDTA, $200 \mu \mathrm{M}$ マロ
Table 2 The composition of AP

\begin{tabular}{lc}
\hline \multicolumn{1}{c}{ Component } & Composition [weight\%] \\
\hline Catechins & 12.9 \\
Procyanidin 2mer & 27.3 \\
Procyanidin 3mer & 11.7 \\
Procyanidin 4mer & 3.5 \\
Procyanidin 5mer & 2.3 \\
Procyanidin 6mer & 1.3 \\
Procyanidin 7mer & 0.9 \\
Procyanidin $\geqq 8 \mathrm{mer}$ & 5.4 \\
Phenol carboxylic acid & 22.3 \\
\hline
\end{tabular}

${ }^{\dagger}$ Procyanidins in apples consist of condensation polymers of catechin and epicatechin.

ニル-CoA, $50 \mu \mathrm{M}$ アセチル-CoA および $300 \mu \mathrm{M} \mathrm{NADPH}$ を含む $0.2 \mathrm{M}$ リン酸カリウムバッファー（pH 7.0）にて反 応を行った. また, サイトゾルの画分 Glucose-6-phosphate dehydrogenase（G6PDH : EC1.1.1.49）活性測定は Dror らの方法に従い26), ペルオキシソーム画分のAcyl-CoA oxidase 活性は Allain らの方法に従い測定した ${ }^{27}$.

3. アディポネクチン, レプチン, インスリンおよび TNF- $\alpha$ の測定

血漿中のアディポネクチン, レプチン, インスリンおよび TNF- $\alpha$ 濃度は市販の ELISA キット（Mouse/rat adiponectin ELISA kit : 大塚製薬社, Rat Leptin ELISA YK 050 : 矢内原研究所, Rat Insulin ELISA kit : Mercodia 社およ び Rat TNF-alpha ELISA YC030 : 矢内原研究所）を用い て測定した。

\section{4. 粪中脂肪酸量の測定}

飼育開始より 45 日間経過後, 2 日間にわたりラットから 粪を個別採取し凍結乾燥保存した。粪中に排泄された脂肪 酸量は Jeejeebhoy ${ }^{28)}$ の方法により測定した。

\section{RNA の調製および遺伝子発現解析}

肝臓および腸間膜白色脂肪の一部を採取し，ただちに RNAlater (タカラバイオ社) に浸漬し冷蔵下一晚保存した. 総 RNA は RNeasy Mini Kit および RNeasy Lipid Tissue Mini kit (キアゲン社)を用いて抽出し, Bioanalyzer 2100 (アジレント社) を用いて定量後, 定量 PCR 解析に供し た. $1 \mu \mathrm{g}$ の総 RNA より cDNA 合成を行った後, Power SYBR Green PCR Master Mix kit（アプライドバイオシ ステム社)を用いて ABI 7700 Sequence Detector（アプラ イドバイオシステム社) による測定を行った. 反応条件は Step $1 ; 50^{\circ} \mathrm{C} 2 \mathrm{~min}$, Step $2 ; 95^{\circ} \mathrm{C} 10 \mathrm{~min}$ および Step 3 ; $\left(95^{\circ} \mathrm{C} 15 \mathrm{~s}\right.$ および $\left.60^{\circ} \mathrm{C} 1 \mathrm{~min}\right) \times 40$ cycles で行った. 得ら れたデータは Glyceraldehyde- 3 -phosphate dehydrogenase 遺伝子 (GAPD) のシグナル值で標準化した。脂質 代謝関連酵素遺伝子である Fatty Acid Synthase 遺伝子, Glucose 6 -Phosphate Dehydrogenase遺伝子および Acyl-CoA Oxidase 遺伝子のプライマー配列はそれぞれ 
forward, 5'-GAGCCGCCGACCAGTATAAA-3', reverse, 5'-GTTGTAATCGGCACCCAAGTC-3', forward, 5' -GTCTTCTGTGGGAGCCAAATG-3', reverse, 5' -ATGGGCTGGGGCTTCTCT-3', forward, 5'-TCTGGTGGATGCCTTTGACTT-3', reverse, 5'-TGTTTTGTTCAGTGGGGATTTCT-3'を用いた. Adiponectin 遺伝子のプライマー配 列は forward, 5'-GGAAACTTGTGCAGGTTGGATG-3', reverse, 5'-GGGTCACCCTTAGGACCAAGAA-3', GAPD のプライマー配列は forward, 5'-GACAACTTTGGCATCGTGGA-3', reverse, 5’-ATGCAGGGATGTTCTGG-3' を用いた。

\section{6. 統計解析}

各実験結果は平均土標準誤差で示し, 一元配置分散分析 ならびにDunnettの多重比較検定による解析を行い, 対 照群に対し $p<0.05$ の場合を有意と判断した。

\section{実 験 結 果}

\section{1. 生育指標と肝臓および血清脂質濃度}

Table 3 に生育指標, 肝臓脂質濃度および血清脂質濃度 を示す. AP は苦味および渋味を呈するが, 摂食量減少や 異常な摂食行動はみられず, また体重増加曲線や粪便の性 状にも異常はみられなかった。 AP 摂取により腎周囲白色 脂肪組織重量ならびに総白色脂肪組織重量が有意に減少し た $(p<0.01)$. 一方, AP 摂取による体重増加量および肝臓 重量の変化はみられなかった（体重増加量; AP $0.2 \%$ 群 $p=0.50, \operatorname{AP} 1 \%$ 群 $p=0.99$, 肝臓重量 ; $\operatorname{AP~} 0.2 \%$ 群 $p=$ 0.89 , AP $1 \%$ 群 $p=0.96$ ).
肝臓トリグリセライド濃度は AP $1 \%$ 群で有意に減少し た $(p<0.05)$ が, 肝臓総コレステロール濃度および肝臓り ン脂質濃度に有意な差はみられなかった。 血清トリグリセ ライド濃度は AP $0.2 \%$ 群で有意に減少した $(p<0.05)$. ま た, 血清総コレステロール濃度に有意な变化はなかった が, AP $1 \%$ 群の血清 HDL-コレステロール濃度は有意に 増加した $(p<0.05)$.

\section{2. 血糖值およびへモグロビン A1c}

一夜絶食後の血糖值およびへモグロビン A 1 濃度を Fig. 1 に示す. AP 摂取により両者は用量依存的な減少傾向を示 し, 血糖値は AP $1 \%$ 群において有意に減少した $(p<0.05)$.

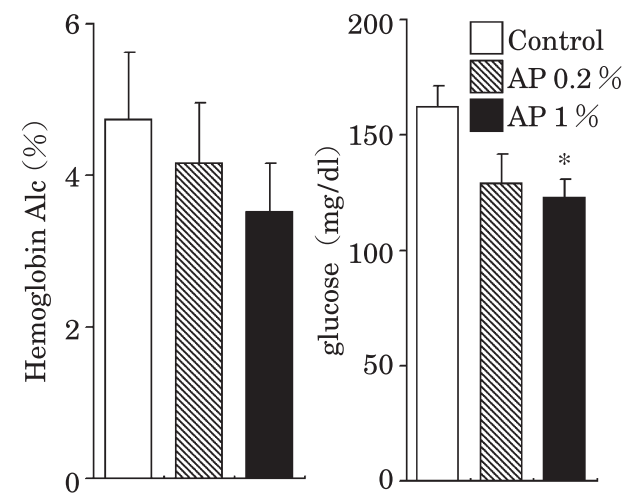

Fig. 1 Blood hemoglobin A1c and glucose level Glucose level in blood was decreased in dose-dependent manner.

Data are presented as mean $\pm \mathrm{SE}$ for 6 rats in each group.

* Significantly different at $p<0.05$.

Table 3 Effect of AP Intake on growth parameters, hepatic lipid levels, and serum lipid levels

\begin{tabular}{|c|c|c|c|}
\hline & \multicolumn{3}{|c|}{ Group } \\
\hline & Control & $\operatorname{AP} 0.2 \%$ & AP $1 \%$ \\
\hline Food intake $[\mathrm{g}]$ & $1701 \pm 12$ & $1701 \pm 7$ & $1696 \pm 17$ \\
\hline Initial BW $[\mathrm{g}]$ & $190 \pm 4$ & $190 \pm 3$ & $190 \pm 3$ \\
\hline Weight gain $[\mathrm{g}]$ & $428 \pm 13$ & $453 \pm 20$ & $435 \pm 21$ \\
\hline Liver weight $[\mathrm{g}]$ & $3.79 \pm 0.30$ & $4.07 \pm 0.20$ & $3.93 \pm 0.60$ \\
\hline Epididymal WAT $[\mathrm{g} / 100 \mathrm{~g}$ of BW] & $2.53 \pm 0.13$ & $2.44 \pm 0.11$ & $2.32 \pm 0.10$ \\
\hline Perirenal WAT $[\mathrm{g} / 100 \mathrm{~g}$ of BW] & $5.28 \pm 0.09$ & $4.48 \pm 0.13^{* *}$ & $4.81 \pm 0.14^{*}$ \\
\hline Mesenteric WAT $[\mathrm{g} / 100 \mathrm{~g}$ of BW] & $1.85 \pm 0.14$ & $1.60 \pm 0.07$ & $1.53 \pm 0.16$ \\
\hline Total WAT $[\mathrm{g} / 100 \mathrm{~g}$ of BW] & $9.66 \pm 0.16$ & $8.51 \pm 0.09^{* *}$ & $8.67 \pm 0.12^{* *}$ \\
\hline Liver triglyceride $[\mathrm{mg} / \mathrm{g}$ liver $]$ & $157 \pm 12.9$ & $131 \pm 13.0$ & $92.4 \pm 6.1^{*}$ \\
\hline Liver total cholesterol $[\mathrm{mg} / \mathrm{g}$ liver $]$ & $6.3 \pm 0.3$ & $6.8 \pm 0.7$ & $6.0 \pm 0.6$ \\
\hline Liver phospholipids [mg/g liver $]$ & $39.1 \pm 1.4$ & $36.6 \pm 1.5$ & $35.7 \pm 1.1$ \\
\hline Serum triglyceride $[\mathrm{mg} / \mathrm{dl}]$ & $402 \pm 92$ & $224 \pm 14^{*}$ & $243 \pm 32$ \\
\hline Serum total cholesterol $[\mathrm{mg} / \mathrm{dl}]$ & $249 \pm 7.9$ & $232 \pm 16$ & $223 \pm 11$ \\
\hline Serum HDL cholesterol $[\mathrm{mg} / \mathrm{dl}]$ & $120 \pm 7.3$ & $124 \pm 4.5$ & $142 \pm 6.9^{*}$ \\
\hline Serum phospholipids $[\mathrm{mg} / \mathrm{dl}]$ & $410 \pm 40$ & $369 \pm 31$ & $398 \pm 28$ \\
\hline
\end{tabular}

Data are presented as mean \pm SE for 6 rats in each groups.

*,** Significantly different at $p<0.05,0.01$, respectively .

Abbreviations : BW, body weight; WAT, white adipose tissue. 
3. 血漿アディポネクチン，レプチン，インスリンおよ び TNF- $\alpha$

Fig. 2 に血漿中のアディポネクチン, レプチン, インス リンおよび TNF- $\alpha$ 濃度を示す。血漿インスリン濃度は用 量依存的に減少し, AP $1 \%$ 群で有意な減少がみられた。ア ディポネクチンは有意な差ではなかったが用量依存的な増 加傾向がみられた（AP 1\%群; $p=0.14 ）$.レプチンおよび $\mathrm{TNF}-\alpha$ 濃度には変化はみられなかった。

\section{4. 䔬中脂肪酸排泄量}

糞中の脂肪酸量を Fig. 3 に示す。 AP 摂取により用量依 存的に粪中脂肪酸量は増加し, AP $1 \%$ 群で有意に増加し
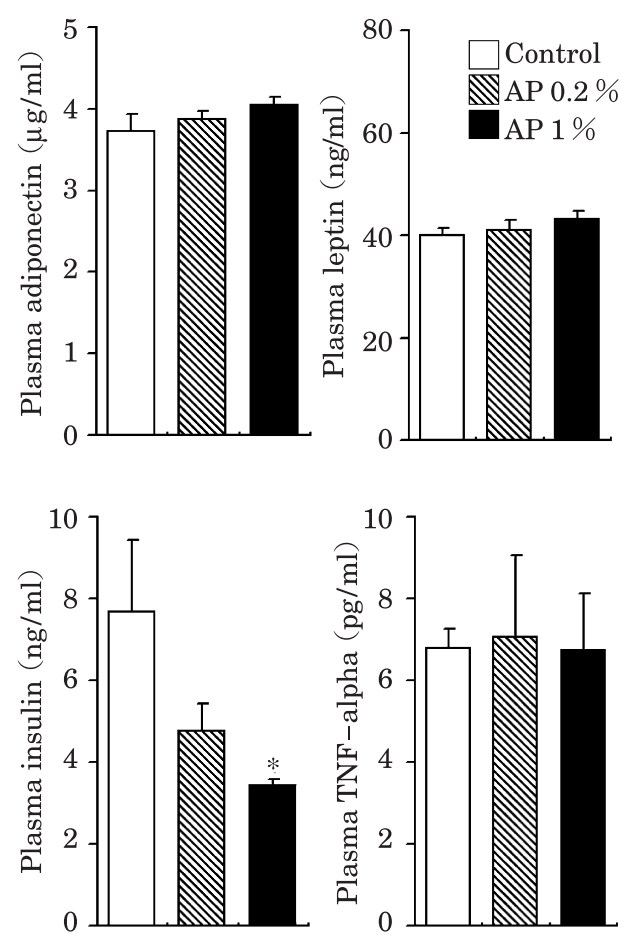

Fig. 2 Plasma cytokines and hormones

Concentrations of cytokines and hormones in plasma were measured using ELISA kits. Insulin level in blood was decreased in dose-dependent manner.

Data are presented as mean $\pm \mathrm{SE}$ for 6 rats in each group.

* Significantly different at $p<0.05$.
た $(p<0.05)$.

\section{5. 脂肪酸代謝酵素活性}

肝臓の Fatty Acid Synthase, Glucose 6-Phosphate Dehydrogenase および Acyl-CoA Oxidase の活性を Table 4 に示す。Fatty Acid Synthase 活性は，AP 摂取により用 量依存的な減少傾向を示したが，有意な差はなかった。 Glucose 6-Phosphate Dehydrogenase の活性および $\beta$ 酸 化系酵素であるAcyl-CoA Oxidase の活性に変化はみら れなかった。

\section{6. 遺伝子発現解析}

肝臓の Fatty Acid Synthase, Glucose 6-Phosphate Dehydrogenase およびAcyl-CoA Oxidase の遺伝子発現量 比ならびに腸間膜白色脂肪組織の Adiponectin 遺伝子発 現量比を Table 5 に示す. Fatty Acid Synthase 遺伝子発 現は AP 䝮取により低下する傾向にあった（AP 0.2\%群； $p=0.109$, AP $1 \%$ 群; $p=0.088$ ). Glucose 6-Phosphate De-

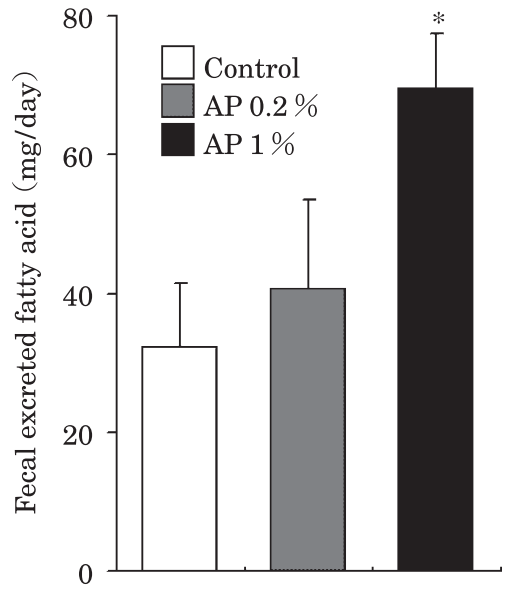

Fig. 3 Fatty acid level in feces

After 45 days of ingestion, feces were collected for 2 days from each rat and then lyophilized. The levels of excreted fatty acids in each group were analyzed according to the method of Jeejeebhoy ${ }^{28}$. Fecal fatty acid was increased in dose-dependent manner.

Data are presented as mean $\pm \mathrm{SE}$ for 6 rats in each group.

* Significantly different at $p<0.05$.

Table 4 Effect of AP Intake on hepatic enzyme activities of fatty acid metabolism

\begin{tabular}{lccc}
\hline \multirow{2}{*}{\multicolumn{1}{c}{ Enzyme }} & \multicolumn{2}{c}{ Activity $(\mathrm{nmol} / \mathrm{min} / \mathrm{mg}$ protein) } \\
\cline { 2 - 4 } & Control & AP $0.2 \%$ & AP $1 \%$ \\
\hline Fatty Acid Synthase & $33.9 \pm 3.6$ & $30.0 \pm 1.9$ & $26.5 \pm 4.0$ \\
Glucose 6-Phosphate Dehydrogenase & $112.3 \pm 3.7$ & $99.6 \pm 12.7$ & $105.71 \pm 19.0$ \\
Acyl-CoA Oxidase & $4.0 \pm 0.5$ & $4.0 \pm 0.4$ & $4.0 \pm 0.3$ \\
\hline
\end{tabular}

Data are presented as mean $\pm \mathrm{SE}$ for 6 rats in each group.

The enzyme activities have been normalized for total protein.

Enzyme activities relative to the control are shown in the next lines.

Hepatic fatty acid synthase activity was slightly decreased by AP intake. 
Table 5 The effect of AP intake on gene expression

\begin{tabular}{lccc}
\hline \hline \multirow{2}{*}{ Gene } & \multicolumn{3}{c}{ Fold Change } \\
\cline { 2 - 4 } & Control & AP 0.2\% & AP 1\% \\
\hline Liver & & & \\
Fatty Acid Synthase & $1.0 \pm 0.17$ & $0.65 \pm 0.09$ & $0.63 \pm 0.07$ \\
Glucose 6-Phosphate Dehydrogenase & $1.0 \pm 0.19$ & $0.95 \pm 0.17$ & $0.94 \pm 0.20$ \\
Acyl-CoA Oxidase 1 & $1.0 \pm 0.06$ & $0.89 \pm 0.05$ & $1.22 \pm 0.16$ \\
\hline WAT & & & \\
Adiponectin & $1.0 \pm 0.10$ & $1.17 \pm 0.11$ & $1.79 \pm 0.19^{*}$ \\
\hline
\end{tabular}

Data are presented as mean \pm SE for 6 rats in each group.

* Significantly different at $p<0.05$.

Genes related to lipid metabolism in liver and Adiponectin gene in WAT were measured quantitative PCR. After normalization of the raw data, values relative to the control were calculated.

Fatty acid synthase gene expression in the liver was slightly decreased by AP intake, while adiponectin gene expression in the WAT was increased.

hydrogenase 遺伝子およびAcyl-CoA Oxidase 遺伝子発 現量に変化はみられなかった。また, 腸間膜白色脂肪組織 の Adiponectin 遺伝子発現量は AP 摂取により用量依存的 に増加傾向がみられ, AP 1\%群では有意に増加していた。

\section{考察}

各群の体重増加量に有意な差はみられなかった。しかし AP 摂取群は, 腎臓周囲白色脂肪組織重量が有意に低值で あった。 また, $\mathrm{AP}$ 摂取群の腸間膜白色脂肪組織と精巣周 囲白色脂肪組織には減少傾向がみられ, 総白色脂肪組織重 量は有意に低值であった。 また，血清トリグリセライド濃 度は, AP 0.2\%群で有意に減少した（対照群; $402 \mathrm{mg} / \mathrm{dl}$, AP $0.2 \%$ 群; $224 \mathrm{mg} / \mathrm{dl}$, AP $1 \%$ 群; $243 \mathrm{mg} / \mathrm{dl}$ )。肝臓卜 リグリセライド濃度は, AP 摂取により用量依存的に減少 し（対照群； $157 \mathrm{mg} / \mathrm{g}$ liver, AP 0.2\% 群 ; $131 \mathrm{mg} / \mathrm{g}$ liver, AP 1\%群; $92.4 \mathrm{mg} / \mathrm{g}$ liver), AP 1\% 群で有意に減少し た。血清トリグリセライド濃度増加抑制効果および内臓脂 肪蓄積抑制効果を示す植物由来ポリフェノールとして，緑 茶力テキン類 ${ }^{8)}$, 力カオ抽出物 ${ }^{29)}$ およびブドウ種子抽出 物 ${ }^{18)}$ などが報告されている。 AP にはプロシアニジン類の 他にカテキン類やクロロゲン酸が含まれ30), これらの化合 物屯脂質代謝改善効果を有すると報告されている ${ }^{7) 31132)}$. 様々なポリフェノールの摂取が脂質プロファイルを改善す るメカニズムとして, 脂質吸収阻害効果が大きな役割を果 たすと考えられている. SugiyamaらはAPに含まれる各 化合物を分画し, カテキン類やクロロゲン酸などの単量体 ポリフェノールに比べ，オリゴマーであるプロシアニジン 類が高い膵リパーゼ阻害活性を有することを明らかにして おり，APの膵リパーゼ阻害活性は主としてプロシアニジ ン類によるあのであることを報告している ${ }^{33)}$. 本動物実験 においては，AP 摂取により糞中脂肪酸量が増加した．こ れは主として膵リパーゼ阻害によるあのと推察される。膵
リパーゼ阻害は腸管での脂肪酸吸収を抑制するため，食餌 からの脂肪酸摂取量が減少し, 結果として脂肪蓄積が抑制 されたと推察される。

また，血清総コレステロール濃度に変化はなかったが, 血清 HDL コレステロールは用量依存的に増加し，AP 1\% で有意な高值を示した. Osada らはコレステロール負荷飼 育通常ラットに対し，AP 摂取が血清総コレステロール濃 度の低減および血清 HDL コレステロール濃度の増加をむ たらし，そのメカニズムはコレステロール吸収抑制による あのであると報告している ${ }^{34)}$.

AP 摂取は血清トリグリセライドおよび肝臓トリグリセ ライド濃度を減少させた。この作用は肝臓での脂肪酸合成 抑制む寄与していると著者らは推測する。なぜなら，本実 験において Fatty Acid Synthaseの酵素活性および遺伝 子発現強度が有意な差ではないむのの低下傾向であったこ とから, 肝臓での脂肪酸合成低下が示唆されるからであ る。筆者らは既に，AP摂取による高脂肪食飼育ラットの 肝臓での脂肪酸合成酵素の活性低下 ${ }^{20)}$, 高脂肪食および通 常食飼育通常ラットの肝茞での脂肪酸合成酵素遺伝子発現 低下 ${ }^{35)}$ を見出しており，カテキン類に関しても同様に脂肪 酸合成抑制効果が報告されている ${ }^{36)}$. AP による脂質指標 の改善は，腸管での消化吸収抑制に加え，AP の脂質代謝 系への直接的な作用も寄与していると考えられる。一方 で，肝臓での脂肪酸合成の低下はカロリ一制限飼育によっ ても生じることが報告されている ${ }^{37)}$. AP 摂取による肝臓 脂肪酸合成の低下が，吸収抑制による摂取カロリ一低下に のみ起因するのか, あるいは肝組織に対するポリフェノー ル成分の直接的な作用が寄与しているのかを明らかにする ため，著者らは検討を進めている.

AP 摂取はインスリン抵抗性に関するパラメータの改善 効果む示した。一夜絶食後の血糖值は用量依存的に減少傾 向にあり，AP 1\%群で有意に低值であった。また，へモグ 
ロビン A $1 \mathrm{c}$ 濃度は有意な差ではないが用量依存的に減少 傾向を示し，飼育期間を通じ血糖值が低く推移したことが 示唆された. さらに, 血漿インスリン濃度む用量依存的に 減少し, AP 1\%群は有意に低值を示した。AP の摂取によ り, Zucker fatty ラットのインスリン抵抗性が緩和された と考えられる。これらのメカニズムとして, アミラーゼ阻 害による糖吸収速度低下が考えられる。 ポリフェノール類 によるアミラーゼ阻害は, 実験動物の食後血糖值上昇抑 制 ${ }^{12)}$ をむらし，空腹時血糖值を低減 ${ }^{738)}$ させることが示 されている. AP む同様のメカニズムにより空腹時血糖值 を低減し, 結果としてインスリン抵抗性抑制に寄与してい ると推察される.

脂肪細胞から分泌されるアディポサイトカインであるア ディポネクチンは, インスリン感受性を高め耐糖能改善に 寄与する ${ }^{39)}$. 本実験では，血漿中アディポネクチン濃度が わずかながら用量依存的に増加していた。 また, 白色脂肪 組織のアディポネクチン遺伝子発現も同様の傾向を示し, AP $1 \%$ で有意に発現上昇した。一方, Li らはいくつかの 植物抽出物の摂取が糖尿病モデルハムスターの耐糖能を改 善し, 血漿アディポネクチン濃度を増大させる ${ }^{40) 41)} こ と$,

Tsuda らはラット脂肪細胞およびヒト脂肪細胞を用いた 実験で，培地中へのアントシアニン添加がアディポネクチ ン遺伝子発現量とアディポネクチン分泌量を増大させるこ

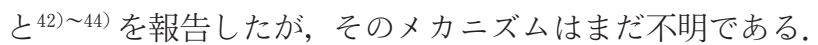
本実験では, AP の摂取により脂肪組織重量増大が抑制さ れた。 APに含まれるポリフェノール化合物が吸収され, 白色脂肪組織に直接作用しアディポネクチン産生を促して いる可能性も考えられる.

近年，ポリフェノールの体内吸収に関する多くの報告が ある. 力テキン類 $\left.{ }^{45} 46\right)$, クロロゲン酸 ${ }^{47) 48)}$ やシアニジン配糖 体 ${ }^{49)}$ などのポリフェノールの経口摂取による, 血中への吸 収や尿からの排泄が報告されている。プロシアニジン類に ついては, Shoji らがラットを用いた実験で, 経口摃取に よるプロシアニジン類の吸収を報告した ${ }^{50)}$. これらのこと から， AP を構成するポリフェノール成分が吸収され，生 体内で直接何らかの作用をもたらしている可能性が考えら れる.

また，ポリフェノールが生物変換された場合には，体内 への吸収率が向上すること ${ }^{51)}$ や，生物変換されたポリフェ ノールでは活性が変化すること ${ }^{52)}$ が推定される. AP を構 成するポリフェノール成分そのもののみならず，生物变換 を受けた代謝物が吸収される可能性もある。代謝物の吸収 率や生理機能性についても今後解明を進めたい.

\section{要 約}

本実験では，肥満モデル動物であるZucker Fatty ラッ トに対し，AP を混合した飼料の摂取がごのような影響を 及ぼすかを検討した。AP 摂取は内臓脂肪蓄積を抑制し,
血清および肝臓トリグリセライド濃度を低減した。また， 血漿インスリン濃度と血糖值を低減した。これらの結果よ り, AP 摂取が脂質代謝とインスリン抵抗性の改善を示す ことが明らかとなった。

\section{文献}

1) Kopelman, P.G., Obesity as a medical problem, Nature, 404, 635-643 (2000).

2) Grundy, S.M., Brewer Jr. H.B., Cleeman, J.I., Smith Jr. S. C. and Lenfant, C., Definition of Metabolic Syndrome : Report of the National Heart, Lung, and Blood Institute/American Heart Association Conference on Scientific Issues Related to Definition, Circulation, 109, 433438 (2004).

3) Ford, E.S., Giles, W.H. and Dietz, W.H., Prevalence of the metabolic syndrome among US adults : Findings from the Third National Health and Nutrition Examination Survey, Journal of the American Medical Association, 287, 356-359 (2002).

4) Eckel, R.H., Grundy, S.M. and Zimmet, P.Z., The metabolic syndrome, Lancet, 365, 1415-1428 (2005).

5) Moller, D.E. and Kaufman, K.D., METABOLIC SYNDROME : A Clinical and Molecular Perspective, Annu. Rev. Med., 56, 45-62 (2005).

6) Kao, Y.H., Hiipakka, R.A. and Liao, S., Modulation of obesity by a green tea catechin, Am. J. Clin. Nutr., 72, 1232-1234 (2000).

7) Crespy, V. and Williamson, G., A review of the health effects of green tea catechins in in vivo animal models, J. Nutr., 134, 3431S-3440S (2004).

8) Wolfram, S., Raederstorff, D., Wang, Y., Teixeira, S.R., Elste, V. and Weber, P., TEAVIGO (epigallocatechin gallate) supplementation prevents obesity in rodents by reducing adipose tissue mass, Ann. Nutr. Metab., 49, 5463 (2005).

9) Hase, T., Komine, Y. and Meguro, S., Anti-obesity Effects of Tea Catechins in Humans. J Oleo Sci, 50, 599-605 (2001).

10) Nagao, T., Meguro, S. and Soga, S., Tea Catechins Suppress Accumulation of Body Fat in Humans. J Oleo Sci, 50, 717-728 (2001).

11) Cabrera, C., Artacho, R. and Gimenez, R., Beneficial effects of green tea--a review, J. Am. Coll. Nutr., 25, 79-99 (2006).

12) Matsumoto, N., Ishigaki, F., Ishigaki, A., Iwashina, H. and Hara, Y., Reduction of Blood Glucose Levels by Tea Catechin, Biosci. Biotechnol. Biochem., 57, 525-527 (1993).

13) Kao, Y.H., Chang, H.H., Lee, M.J. and Chen, C.L., Tea, obesity, and diabetes, Mol. Nutr. Food Res., 50, 188-210 (2006).

14) Ohnishi-Kameyama, M., Yanagida, A., Kanda, T. and Nagata, T., Identification of catechin oligomers from apple (Malus pumila cv. Fuji) in matrix-assisted laser desorption/ionization time-of-flight mass spectrometry and fast-atom bombardment mass spectrometry, Rapid Communications in Mass Spectrometry, 11, 31-36 (1997).

15) Yanagida, A., Kanda, T., Takahashi, T., Kamimura, A., Hamazono, T. and Honda, S. Fractionation of apple procyanidins according to their degree of polymerization by normal-phase high-performance liquid chromatography, Journal of Chromatography A, 890, 251-259 (2000).

16) Shoji, T., Mutsuga, M., Nakamura, T., Kanda, T., Akiyama, 
H. and Goda, Y. Isolation and structural elucidation of some procyanidins from apple by low-temperature nuclear magnetic resonance, Journal of Agricultural and Food Chemistry, 51, 3806-3813 (2003).

17) Shoji, T., Masumoto, S., Moriichi, N., Kanda, T. and Ohtake, Y., Apple (Malus pumila) procyanidins fractionated according to the degree of polymerization using normalphase chromatography and characterized by HPLCESI/MS and MALDI-TOF/MS, Journal of Chromatography A, 1102, 206-213 (2006).

18) Nakamura, Y. and Tonogai, Y., Effects of Grape Seed Polyphenols on Serum and Hepatic Lipid Contents and Fecal Steroid Excretion in Normal and Hypercholesterolemic Rats. J Health Sci, 48, 570-578 (2002).

19) Schonlau, F. and Rohdewald, P., Pycnogenol for diabetic retinopathy. A review, International Ophthalmology, 24, 161-171 (2001).

20) Osada, K., Effect of Dietary Procyanidins and Tea Polyphenols on Adipose Tissue Mass and Fatty Acid Metabolism in Rats on a High Fat Diet. J Oleo Sci, 55, 7989 (2006).

21) Shoji, T., Akazome, Y., Kanda, T. and Ikeda, M., The toxicology and safety of apple polyphenol extract, Food Chem. Toxicol., 42, 959-967 (2004).

22) Akazome, Y., Kanda, T., Ohtake, Y., Hashimoto, H., Kametani, N., Sato, K., Nakamura, T. and Kajimoto, Y., Evaluation of safety of excessive intake and efficacy of long term intake of beverage containing polyphenols derived from apples, Japanese Pharmacology and Therapeutics, 33, 893-911 (2005).

23) Folch, J., Lees, M. and Sloane-Stanley, G.H., A simple method for the isolation and purification of total lipids from animal tissues. J. Biol. Chem., 226, 497-506 (1957).

24) Osada, K., Inoue, T., Nakamura, S. and Sugano, M., Dietary protein moderates the deleterious disturbance of lipid metabolism caused by exogenous oxidized cholesterol in rats. Biochim. Biophys. Acta, 1427, 337-350 (1999).

25) Nepokroeff, C.M., Lakshmanan, M.R. and Porter, J.W., Fatty-acid synthase from rat liver, Methods Enzymol., 35, 37-44 (1975).

26) Dror, Y., Sassoon, H.F., Watson, J.J. and Johnson, B.C., Glucose 6-phosphate dehydrogenase assay in liver and blood, Clin. Chim. Acta, 28, 291-298 (1970).

27) Allain, C.C., Poon, L.S., Chan, C.S., Richmond, W. and Fu, P.C., Enzymatic determination of total serum cholesterol, Clin. Chem., 20, 470-475 (1974).

28) Jeejeebhoy, K.N., Ahmad, S. and Kozak, G., Determination of fecal fats containing both medium and long chain triglycerides and fatty acids, Clin. Biochem., 3, 157-163 (1970).

29) Matsui, N., Ito, R., Nishimura, E., Yoshikawa, M., Kato, M., Kamei, M., Shibata, H., Matsumoto, I., Abe, K. and Hashizume, S., Ingested cocoa can prevent high-fat dietinduced obesity by regulating the expression of genes for fatty acid metabolism, Nutrition, 21, 594-601 (2005).

30) Kanda, T., Akiyama, H., Yanagida, A., Tanabe, M., Goda, Y., Toyoda, M., Teshima, R. and Saito, Y., Inhibitory effects of apple polyphenol on induced histamine release from RBL-2H3 cells and rat mast cells, Biosci. Biotechnol. Biochem., 62, 1284-1289 (1998).

31) Murase, T., Nagasawa, A., Suzuki, J., Hase, T. and Tokimitsu, I., Beneficial effects of tea catechins on dietinduced obesity : stimulation of lipid catabolism in the liver, Int. J. Obes. Relat. Metab. Disord., 26, 1459-1464 (2002).

32) Rodriguez de Sotillo, D.V. and Hadley, M., Chlorogenic acid modifies plasma and liver concentrations of : cholesterol, triacylglycerol, and minerals in (fa/fa) Zucker rats, J. Nutr. Biochem., 13, 717-726 (2002).

33) Sugiyama, H., Akazome, Y., Shoji, T., Yamaguchi, A., Yasue, M., Kanda, T. and Ohtake, Y., Oligomeric Procyanidins in Apple Polyphenol are Main Active Components for Inhibition of Pancreatic Lipase and Triglyceride Absorption, Journal of Agricultural and Food Chemistry, Submitted.

34） Osada, K., Suzuki, T., Kawakami, Y., Senda, M., Kasai, A., Sami, M., Ohta, Y., Kanda, T. and Ikeda, M., Dosedependent hypocholesterolemic actions of dietary apple polyphenol in rats fed cholesterol, Lipids, 41, 133-139 (2006).

35) Ohta, Y., Sami, M., Kanda, T., Saito, K., Kato, H. and Osada, K., Gene Expression Analysis of the Anti-obesity Effect by Apple Polyphenols in Rats Fed a High Fat Diet or a Normal Diet, J Oleo Sci, 55, 305-314 (2006).

36) Tian, W.X., Inhibition of fatty acid synthase by polyphenols, Curr. Med. Chem., 13, 967-977 (2006).

37) Feuers, R.J., Duffy, P.H., Leakey, J.A., Turturro, A., Mittelstaedt, R.A. and Hart, R.W., Effect of chronic caloric restriction on hepatic enzymes of intermediary metabolism in the male Fischer 344 rat, Mechanisms of Ageing and Development, 48, 179-189 (1989).

38) Liu, X., Zhou, H. and Rohdewald, P., French maritime pine bark extract Pycnogenol dose-dependently lowers glucose in type 2 diabetic patients, Diabetes Care, 27, 839 (2004).

39) Yamauchi, T., et al., The fat-derived hormone adiponectin reverses insulin resistance associated with both lipoatrophy and obesity, Nature Medicine, 7, 941-946 (2001).

40) Li, R.W., Douglas, T.D., Maiyoh, G.K., Adeli, K. and Theriault, A.G., Green tea leaf extract improves lipid and glucose homeostasis in a fructose-fed insulinresistant hamster model, Journal of Ethnopharmacology, 104, 24-31 (2006).

41) Li, R.W., Theriault, A.G., Au, K., Douglas, T.D., Casaschi, A., Kurowska, E.M. and Mukherjee, R., Citrus polymethoxylated flavones improve lipid and glucose homeostasis and modulate adipocytokines in fructoseinduced insulin resistant hamsters, Life Sciences, 79, 365-373 (2006).

42) Tsuda, T., Ueno, Y., Aoki, H., Koda, T., Horio, F., Takahashi, N., Kawada, T. and Osawa, T., Anthocyanin enhances adipocy tokine secretion and adipocyte-specific gene expression in isolated rat adipocytes, Biochem. Biophys. Res. Commun., 316, 149-157 (2004).

43) Tsuda, T., Ueno, Y., Kojo, H., Yoshikawa, T. and Osawa, T., Gene expression profile of isolated rat adipocytes treated with anthocyanins, Biochim. Biophys. Acta Mol. Cell Biol. Lipids, 1733, 137-147 (2005).

44) Tsuda, T., Ueno, Y., Yoshikawa, T., Kojo, H. and Osawa, $\mathrm{T}$., Microarray profiling of gene expression in human adipocytes in response to anthocyanins, Biochem. Pharmacol., 71, 1184-1197 (2006).

45) Masukawa, Y., Matsui, Y., Shimizu,N., Kondou, N., Endou, H., Kuzukawa, M. and Hase, T., Determination of green tea catechins in human plasma using liquid 
chromatography-electrospray ionization mass spectrometry, J. Chromatogr. B. Analyt Technol. Biomed. Life. Sci., 834, 26-34 (2006).

46) Feng, W.Y., Metabolism of green tea catechins: An overview, Current Drug Metabolism, 7, 755-809 (2006).

47) Lafay, S., Gil-Izquierdo, A., Manach, C., Morand, C., Besson, C. and Scalbert, A., Chlorogenic acid is absorbed in its intact form in the stomach of rats, Journal of Nutrition, 136, 1192-1197 (2006).

48) Lafay, S., Morand, C., Manach, C., Besson, C. and Scalbert, A., Absorption and metabolism of caffeic acid and chlorogenic acid in the small intestine of rats, British Journal of Nutrition, 96, 39-46 (2006).

49) Tsuda, T., Horio, F. and Osawa, T., Absorption and metabolism of cyanidin 3-O-beta-D-glucoside in rats, FEBS Lett., 449, 179-182 (1999).

50) Shoji, T., Masumoto, S., Moriichi, N., Akiyama, H.,
Kanda, T., Ohtake, Y. and Goda, Y., Apple procyanidin oligomers absorption in rats after oral administration: Analysis of procyanidins in plasma using the porter method and high-performance liquid chromatography/ tandem mass spectrometry, Journal of Agricultural and Food Chemistry, 54, 884-892 (2006).

51) Wen, X. and Walle, T., Methylated flavonoids have greatly improved intestinal absorption and metabolic stability, Drug Metabolism and Disposition, 34, 1786-1792 (2006).

52) Gonthier,M.P., Remesy,C., Scalbert, A., Cheynier, V., Souquet, J.M., Poutanen,K. and Aura, A.M., Microbial metabolism of caffeic acid and its esters chlorogenic and caftaric acids by human faecal microbiota in vitro, Biomed. Pharmacother., 60, 536-540 (2006).

(平成 19 年 2 月 26 日受付，平成 19 年 3 月 19 日受理) 